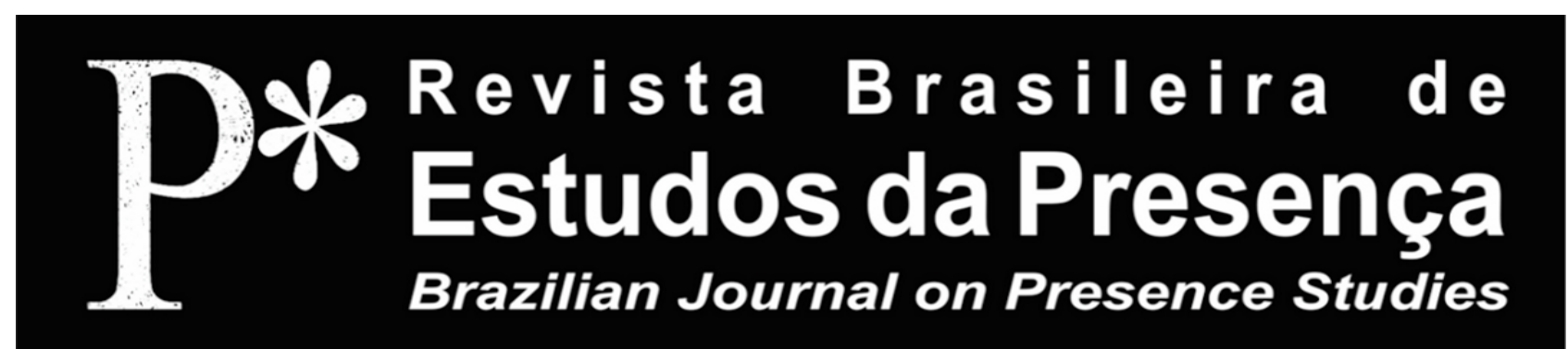

PERFORMANCE PHILOSOPHY

E-ISSN 2237-2660

\title{
The Performative Nature of Dramatic Imagination
}

\author{
Rubén Vega Balbás \\ 'Universidad Nebrija - Madrid, Spain
}

ABSTRACT - The Performative Nature of Dramatic Imagination - Creative imagination is a central concept in critical philosophy which establishes the framing faculty of the subject in the middle of the cognitive process. Linking the internal and the external, imagination is also key for dramatic acting methodologies. This mediation has been alternatively interpreted in Western tradition under a reversible perspective, giving priority to either the process that goes from the outside inwards (aesthesis) or just the opposite (poiesis). Going beyond dialectics, this article will connect philosophy with dramatic theory. My proposal explores the virtual drama of identity to emphasise how the transcendental and empirical get linked theatrically.

Keywords: Imagination. Drama. Performance. Acting. Performance Philosophy.

RÉSUMÉ - La Nature Performatif de l'Imagination Créatice - L'imagination créatrice est un concept central de la philosophie critique qui établit la faculté de cadrage du sujet, dans la mesure où elle joue le rôle de médiateur entre le monde mental et le monde matériel, au milieu du processus cognitif. Liant l'imaginaire à l'externe, l'imagination est également essentielle pour les méthodologies du jeu dramatique. Cette médiation a été interprétée alternativement dans la tradition occidentale selon une perspective réversible, en donnant la priorité soit au processus allant de l'extérieur vers l'intérieur (aesthesis), soit au contraire (la poiesis). Au-delà de la dialectique, cet article associera la philosophie à la théorie dramatique. Ma thèse explore le drame virtuel de l'identité et, si l'imagination et les actes performatifs dépendent les uns des autres en tant que poursuites humaines, avec le terme dramatisation je souligne comment le transcendantal et l'empirique sont liés théâtralement.

Mots-clés: Imagination. Drame. Performance. Jeu. Philosophie de la Performance.

RESUMO - A Natureza Performativa da Imaginação Dramática - A imaginação criativa é um conceito básico na filosofia crítica, que baseia a faculdade de enquadramento do sujeito no centro do processo cognitivo. Ligando o interno e o externo, a imaginação também é fundamental para as metodologias de interpretação dramática. Esta mediação foi alternativamente interpretada na tradição ocidental sob uma perspetiva reversível, ora priorizando o processo que ocorre de fora para dentro (aestesis), ora o oposto (poiese). Para além de dialética, o artigo irá relacionar a filosofia com a teoria dramática, explorando o drama virtual da identidade, de modo a enfatizar como o transcendente e o empírico se ligam teatralmente.

Palavras-chave: Imaginação. Drama. Performance. Interpretação. Filosofia da Performance. 
For Marcos Ferreira-Santos, mestre do imaginário, and for Layla Benitez-James, with gratitude.

In order to emphasise the advantage of empiric methodologies concerning imagination and drama research, I would like to start the discussion with neither the platonic dialogues nor Aristotle's De Anima, neither the Scholastics nor the Renaissance, neither Kant nor German idealism, neither the hermeneutic school nor from any of the postmodernist attempts to overcome metaphysics. If the episode that I am about to relate expanded my perspective on the action and identity binomial, it is because of the interplay between text and context, between observer and scene, that is to say, because of it being theatrical. In a boxing gym in the suburbs, stuck to the wall, amidst images of local heroes and hall of famers, was a big poster and, written on it, as a motivational adage, a quote by the Uruguayan man of letters, Eduardo Galeano. Some youngsters were working out, loudly punching the heavy bag when a ray of sun entered from a window, lighting the phrase rudely handwritten in capital letters WE ARE WHAT WE DO / TO CHANGE WHAT WE ARE.

\section{Introduction. The big drama show (of the visible and invisible)}

Trying to focus on the interactions between identity and performance after ten years of research - interspersed with an always evolving professional career in theatre-, my mind was still held captive by the matter as I had defended my Ph. D. a few months before, when that vision appeared before me as a striking synthesis. The quote, which Marxists all over the world had made their own, emphasises how every approach to the question of identity ends up trapped in self-reference and recursion, and, under the repetitive mantra of the anti-essentialist theories, I appreciate the impossibility of running out permanently from a given kind of substance to be remembered. As I had not taken notice of it when I read El libro de los abrazos (The Book of Embraces, 2016 [1989], p. 92), I could not finish with the quote placed at the dissertation's epigraph. Instead I referred to R. Dimsdale Stocker (2014, p. 77), an almost unknown British spiritual humanist who, at the beginning of the 20th century, put it in other words "We are, as we behave. As we do, we become". More obscure, but relevant as a warning of the risks of the question, I am reminded of Bauman (1996, 
p. 19) advising that "Identity is a critical projection of what is demanded", and Lévi-Strauss (1983) in the 1974-75 course at the Collège de France, stressing identity as "[...] a sort of virtual home which we find indispensable as a point of reference when explaining a certain number of things, without, however, it ever having any real existence" (apud Pultar, 2014, p. 13). For its part, I think that what Rimabud wrote in a letter to his teacher, George Izambard, in 1871 - Je est un autre - deserves to be honoured on the wall in a boxing gym. The glimmer of light, the smell of perspiration and the muted sound of hitting were ensuring that for those subjects in gloves, change was for real, and they had no doubt about action being the way to accomplish the change in the most dramatic sense. The day was settling down and the last light before evening was giving way to the kingdom of phantoms to come. Most of the boys and girls there shadow boxing were already three-rounders in local professional undercards, although some of them had even achieved title bouts in other states. They used to come to the gym on Friday evenings, after ordinary people and amateurs had left for dating, the movies, or family dinner. Thus, they were not just there for fitness but to become one's own alter. As a super-objective in sports and in life, they were all trying to leave the gloom of gym fights in exchange for the lights of big shows; they were not looking for an identity, they were just imagining a breakthrough to be possible.

The theory was being asserted before my eyes more convincingly than it had in any of my readings; in theatre, as in life, all that's needed is enlightenment from a virtual projection for action to take over. It is known that every boxer believes that becoming the champion of the world is a possibility, that even under punishment against the ropes, victory is always possible, that a single action can transform reality from the inside out. A collective dramatic faith derives from the shared phantasy that becoming another is possible - if you are already someone. Winning the belt is not a possibility grounded in statistics, it is nothing less than a phantasy which action can turn into reality in a flash because, as Deleuze explains in his text about dramatization, plausibility is the opposite of reality, not virtuality (Deleuze, 2002 [1967]). Under adequate lighting, action's power is verified to transform any imaginable virtuality into a fact: Deleuzeans and boxers take this as a given. Although the theatre of the self is to be performed out in the spotlight, before the cameras arrive, before the fans are to applaud one's 


\section{Revista Brasileira de Estudos da Presenca Brazilitan Journal on Presence Studies}

name, it is necessary to face the shadows of gyms, to become one of them, because dreams ought to be dreamt before eventually coming true.

Light is the ancient symbol of Knowledge, of Science. As Dionysius is of Comedy, Apollo, the god of Tragedy, is also of Light. In our world, completely populated with liquid crystal displays, concealing darkness, the Eye King lives and reigns as a sovereign master. Before pay-per-view, the Situationist Movement announced the specular reality becoming a global aberration; their advice was unable to avoid it becoming a reality. Even Plato's Allegory of the Cave can be thought of as an admonition for how the eye can be tricked by the movement of shadows that light generates. But long before capitalist society developed the industry of visual entertainment globally by means of perverting images in simulacra, ancient Indian philosophy knew about the third eye, not visible on the face, responsible for consciousness. The punch that is not seen coming in, is the punch that knocks one out. Identity fluctuates between the excess of exhibition and total invisibility.

I am the 'me' I see, and also the 'me' that I do not see. Both of those 'mes' are essential; one cannot exist without the other. How can the actor create this invisible part? (Donnellan, 2008, \$9).

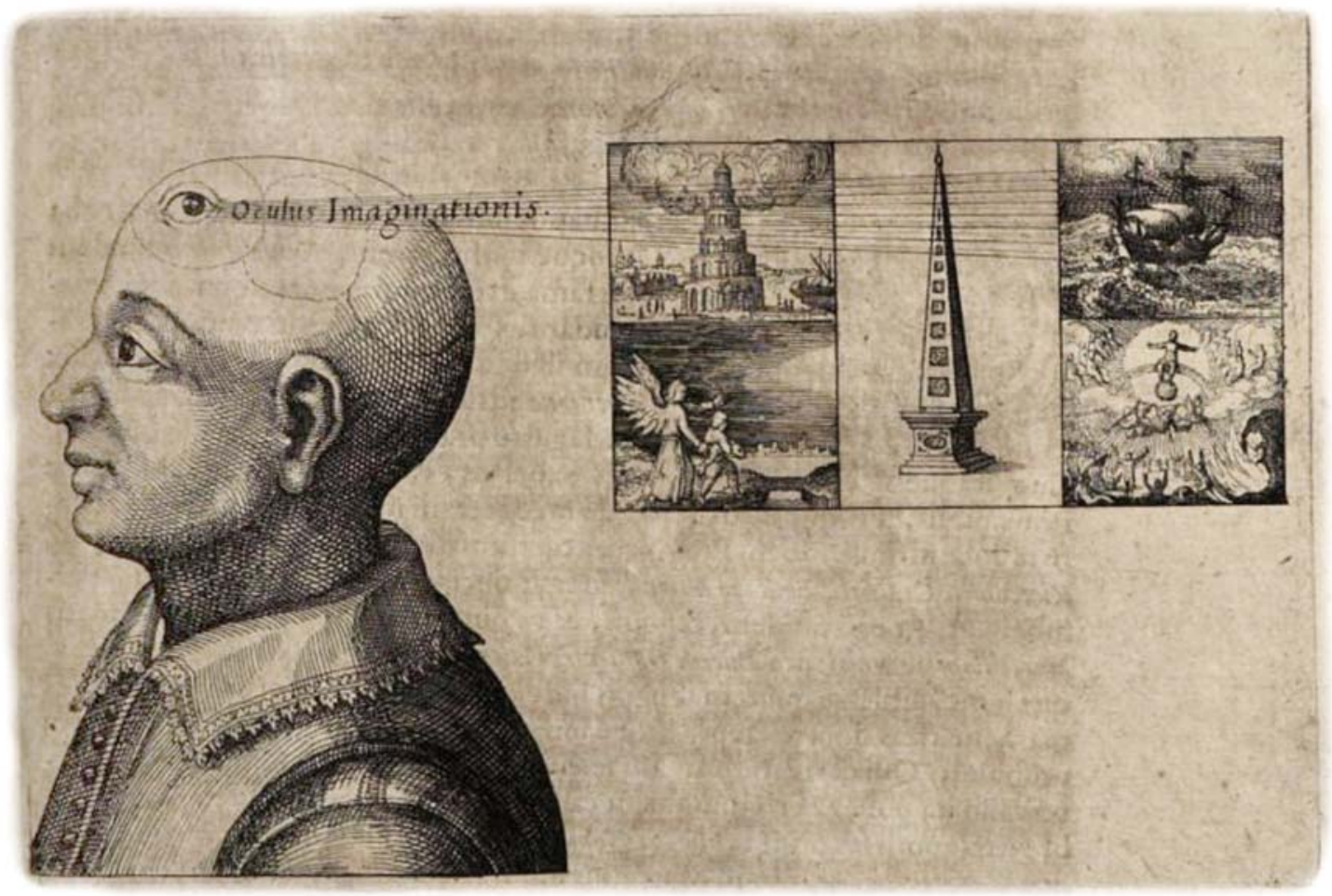

Figure 1 - Oculus Imaginationes. Ars Memoriæ. Source: Fludd (1619, p. 47). 
If the term is to be accepted - after being revealed to mean too little, too much, or nothing at all (Brubaker; Cooper, 2000), - identity - whatever it may mean and considered only through symbolic interaction - can be defined as the performance that comes from that which exists - the existent - and creates its own status through self-reflection. If identity is considered to be real, reality is to be imaginary. Seen from the opposite angle, avoiding the terminology for identity, avoiding recursion, and adopting a constructivist perspective, it is reasonable to accept that imagination is always performative as identity is always dramatic. Etymologically, action derives from $\delta \rho \tilde{\alpha} \mu \alpha$ - drama - and imagination derives both from light and visible resemblance to be claimed in its own right as a creative constitutive faculty of the subject's critical thinking. Heir to the ancient dualistic opposition with the occult, light authorizes representative images to the discredit of phonies, while imagination is hereafter defended as an autonomous dynamism that leads consciousness to easily reveal itself out of brightness or shadows. As the ancient dominance of Osiris over Typhon, the prevalence of the visible reinforces logical against mythical thinking, making us latch on to scientific method as Narcissus did to images, falling in love with our own reflection. Now that images are ubiquitous regardless of their being fake or real, I believe it is worth the attempt to re-think imagination as the drama of consciousness, beyond the predominance of the sense of sight, giving light back to its mystical origin in spite of literality.

\section{Now blow the candle out...}

During sleep, reason cancelled, the mind creates a self-sufficient context of existence. It is not necessary to wish the dreams come true: they already are. Eyes closed, during that second of silence before the candlelight extinguishes, images are totally mental, but not for that reason unreal. I can imagine; therefore, I can image that I exist. The object of my purpose does not need to be materialized in front of my eyes in order to confirm the true existence of my wishing (un)consciousness, that which emerges precisely from the free act of symbolic projection.

Following etymology, most of the philosophic literature in West tradition chains imagination to iconicity, that is to say, to visible resemblance, yet I think that compromising the tradition of terminology, 
associating instead imagination with magic, represents a shift that can better fits performative imagination for discussion. I agree with Glenn Most that "[...] a more satisfying theory of the imagination in ancient Greece might prefer popular sources on magic, religion, and emotion to the philosophers' discussions" (apud Shulman 2012, p. 311). Mostly disregarded in scientific discourses, the wide roots of magical imagination and its mythical foundations in Western esotericism have been fruitfully explored by Antoine Faivre (2000, p. 99-136). Magus is a term that we know precedes Greek terminology and, in consequence, it results useful to overriding dialectics not dialectically. Contrary, Latin imago, imitation, connects with the Greek cik $\alpha \sigma i \alpha$ (eikasia), a term that played a main role in the constitution of the scientific methodology that dialectically separates appearances from true knowledge. As the Platonic philosopher pursues regarding Ideas, and as Ideas require a theatre to manifest themselves - a place from where being beheld, a body to inhabit -, therefore theatre and dialectical philosophy meet with each other dramatically confronting false images, deceiving reflections, and phantoms. In logical visual systems as ours, and were also the Platonic Republic and the Augustinian City of God, imagination cannot be totally abrogated, but must be sufficiently domesticated; albeit a hazard, as it can move the soul and its feelings, imagination is also hoarded by Science as our only interface to interact with reality. Materia sensibus signata, as Aquinas described it - the quantifiable reality already actualized -, can only be apprehended through the senses, can only be imagined as we can only aspire to admire the show of truth from the dark side of the theatre. "Who are the true philosophers?" Plato's older brother, Glaucon, incisively asked in The Republic. "Those for whom the truth is the spectacle of which they are enamoured" answered Socrates (Plato et al. 1914, V,475e). Philosophers aim to apprehend the truth imaginatively while magicians are concerned with the imaginary nature of truth. What about artists? Artistry should withstand as a space of freedom for imagination to remain funny, crazy, or silly, without thereby ceasing to connect the perishable and the sublime.

Dialectical reason is logical; thus, a non-questionable state of preexistence must be assumed. In consequence, Ideas, which are immanent, cannot be imaginary: imagination brings us the experience of truth, but understanding reality as the fractal result of an imaginative transpersonal 
power is not so logically arguable - that would be the same as admitting that the myth of the Theatrum Mundi is not allegorical but literal. Poetical imagination neither can be considered to the letter capable of bringing the non-being into being as if poiesis were sorcery; even the famous statement in Symposium (205c) was not Socrates' but Diotima's, the prophet of love. Fertility, war, and love are associated with imaginative feminine magic from multiple perspectives (Pollock; Turvey Sauron, 2007). Circe, Aphrodite, Tanit, Isthar, Inanna, Isis, and going back as far as to the Neolithic Venus, feminine deities represented by the Morning Star are also related with the descensus ad infernos, and the afterlife. The creative faculty of the soul may compromise the whole logical system if considered magical: one could be blowing out the wishing cake as if every day were one's very merry unbirthday.

According to Porphyry, the Phoenician, in the Persian tongue magus refers to "divinorum interpres et cultor" (apud Pico della Mirandola et al. [1486] 2012). Magi in the Eastern tradition, sacerdos in Latin, were worshippers and interpreters of the divine. By way of analogy, magicians can recognise that which being visible is only seen for the initiated dreams, mirrors, and celestial bodies through which the natural order selfmanifests -, and by way of resonance, they can exert their influence over the ordering. Imagination is not only a productive mechanism, it also constitutes the natural essence of all what exist in transformation, or, in the words of Aristotle about the soul, "imagination must be a movement resulting from an actual exercise of a power of sense" (Aristotle, 1908, 3:III, 428b-429a). Also, this famous reading on producing and becoming appeals to the metaphor of light to explain how potency radiates over the actual "as a kind of disposition ( $\check{\varepsilon} \xi \iota \varsigma) ”($ Aristotle, 1993, p. 60), and disposition is a key for the non-essentialist theories on the identity-performance binomial. Poiesis is mimetic and produces phenomena, while magic is analogical and brings knowledge of a geometric, recursive, and unceasingly transformative reality; both, magic and poiesis, get together for the sacred dance of Shiva, irradiator of cosmic power. According to Plotinus (1918), Porphyry's instructor, imagination is the nature of the cosmic architecture, and a magus is the minister of nature and not merely its artful imitator (apud Pico della Mirandola et al., [1486] 2012, p. 425). Aesthetics rejects mockery, false forms, as epistemology tries to cancel magic once and for all, 
not only the spurious one but totally, because every kind of magic compromises the chronological flow and the continuity of space, driving consciousness to a suspended momentum.

\section{This magic moment \\ While your lips are close to mine \\ Will last forever \\ Forever, 'til the end of time \\ So why won't you dance with me $e^{I}$}

Linking the study of imagination to magic corresponds with the specular intention of Bruno's drawing on imagination to describe the magical order. Furthermore, this linking requires one more key to be understandable: memory. As during gestation, poetical imagination projects itself towards the future, whilst magical imagination takes actuality into an etheric plane, the plane of lightness and reminiscence, The Anfiteatro della memoria (Theatre of memory, Camillo, 2007 [1554], p. 8), or "the subtle world of the Soul, the world of Malakût, mundus imaginalis. Others have spoken of the "Chronicle of Akasha"' (Corbin, 1989, p. xvii). The demiurge impersonates a figure in the theatre of philosophy that has contributed to legitimate the exclusionary consideration of a single Supreme Creator, but cosmic imagination, as brought by Proclus (2007, p. 143) in his commentary to Plato's Timaeus, more fertilely represents the sensitive state of intuitive thinking, which "has in it invisible impressions of the sensibles that come to be in the entire history of the cosmos". Referring to Bruno in De Vinculis in Genere (A general account of bonding, 1879, v. III), magical imagination enacts as the chain of chains (vinculum vinculorum) unveiling the unseen, and linking the internal with the external, the material with the spiritual, reality and dreams, your lips and mine.

Duality does not necessarily imply dialectics. Logical reasoning can only deploy its method if polarities are mutually exclusive, and in the absence of any other third element that could make possible a non-true / false state of play. Monism never neglected dualisms like the parts of a thing do not deny its autonomy. For the development of dramatic philosophy, imagination has been, however, repeatedly split between poetics and aesthetics. The Einbildungskraft / Phantasie (imagination / phantasy) distinction probably should be credited to Ernst Platner's influential work Anthropologie für Aerzte und Weltweise (Anthropology for physicians and the 
worldwise, 1791 [1772]). English romantic poets - Coleridge (1984) and Wordsworth - like German Idealists - Fichte, Schelling, and Goethe invoked this lexicon to distinguish the productive imagination - which is lived (lebhaft) - from phantasy -which is mechanical (mechanische). But it was Kant who acknowledged imagination as a determinant creative faculty, and the discussion of its role with respect to cognition and perception is one among the most noteworthy contributions by critical philosophy; it has become as decisive in the conceptualizing of the autonomous subject as for the flourishing of sciences. In spite of rationalism giving it a special status in the differentiated ontological and epistemological systems, separated from phantasy, synthetical imagination assures the persistence of diacritic excisions - between the physical and that which is beyond the physical, between inside and outside, object and subject, knowledge and being. The dialectical method, by creating dissimilar polarities, isolates imagination from myth-magical thinking. Whatever differs logical reasoning results consequentially subsumed, abrogated as a constitutive pitfall. Deleuze, in his fourth lesson on Kant, explains that imagination results much more valorised when, in addition to the production of images, it is recognized as an indispensable faculty for the determination of space-time. "What does a mathematician or a geometer do? Or in another way, what does an artist do? They're going to make productions of space-time" (Deleuze, 1978, n.p.). Although this idea can resonate with the magical suspension, the result of Einbildungskraft - that faculty which might be better translated in any other way than imagination - is to produce a subjective experience of disposition. For its part, magical imagination does not exclude phantasy, denominated facultati fingendi by Kant (1997, p. 49), as deception is requisite for the art of theatre. 


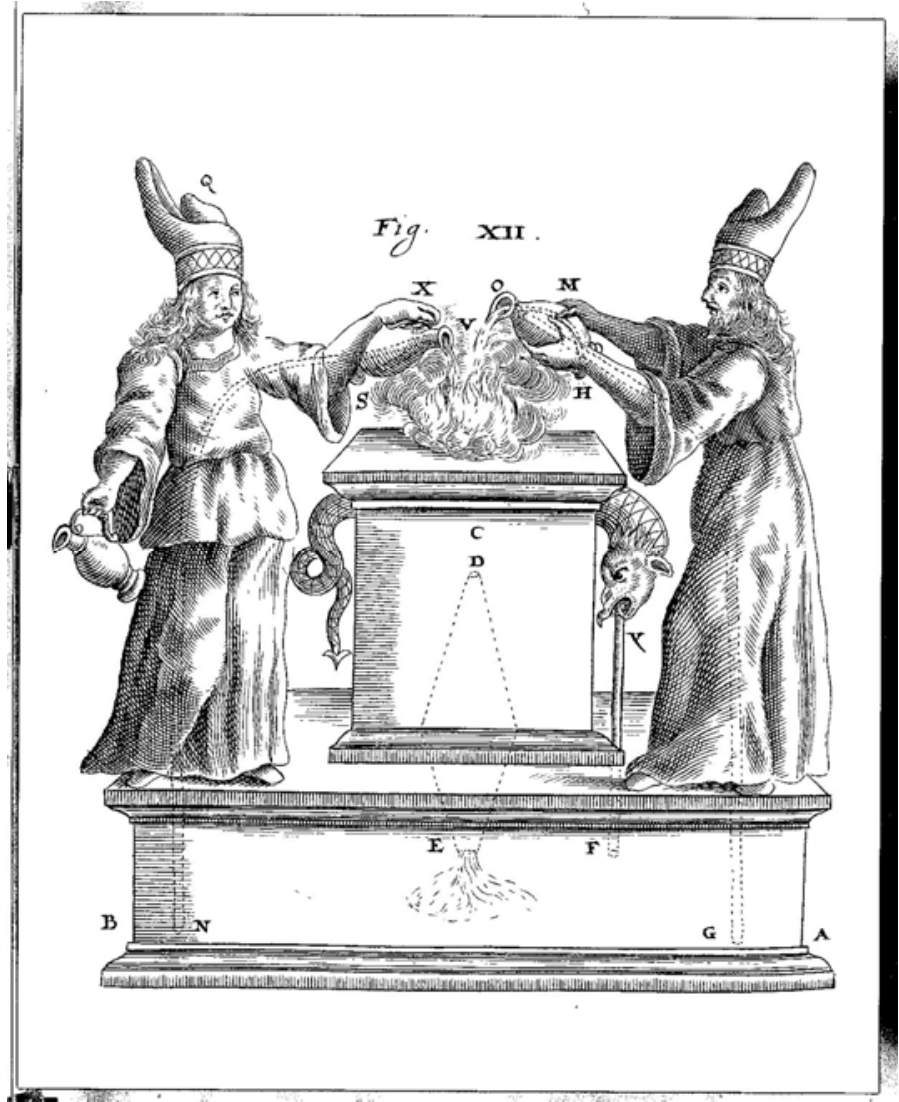

Figure 2 - Illustration by Athanasius Kircher showing the technology behind the Isis and Osiris magic; included in Mechanica Hydraulico-Pneumatica (Schott, 1657, p. 245).

Source: Athanasius Kircher Correspondence Project.

The poetical imagination

If critical rationalism had neglected phantasy as secondary cognitive process in contrast with the centrality of productive reasoning, symbolic anthropology did the opposite. Durand's best known monographs - Les Structures anthropologiques de l'imaginaire (The Anthropological Structures of the Imaginary, 1960) and L'Imagination symbolique (The Symbolic Imagination, 1964) - are dedicated to the symbolism of creative thinking, extending anthropology via mythological analysis. Instead of imagination, Durand conceives l'imaginaire (the imaginary) as a metaphysical field related to the ontological projection of personal creative expression. Jung and Lévi-Strauss, as did Duran, analysed human symbolism within the framework of structuralism and, recognizing the centrality of linguistic symbolization, studied mythical, ritual and religious experiences.

In contrast with productive, poetical imagination refers to the sustained meaning that metaphorical thinking enables. Poetical imagination also 
concerns feeling and cognition, as Ricœur ventured (1978b), translating the phenomenon into a range of hermeneutics - where veritable reality is not pursued. The geneses of the poetical imagination can be traced to the same mysterious source where language as a symbolic aptitude of the species streams from. Against the suggestive invocation of memories and the interplay of phantasies, beyond the dialectics of production / reproduction, Bachelard was among the first to claim with vigour that imagination was a "major power of human nature" (1961 [1957], p. 16). Thus, he can rightfully be recognized as a philosopher of the imagination. Within his legacy, many aspects could be highlighted to show how imagination concerns drama, as it can make matter interact with psyche. Also, in $L a$ poetique de l'espace (The Poetics of Space), he stresses that imagination reveals itself through vives actions (lively actions) looking forward to the future (ibid). Towards a psychology of the imagination, Bachelard, in L'Eau et les Rêves (Water and Dreams, 2016 [1942]), insists on its materiality, and in La Psychanalyse du feu (The Psychoanalysis of Fire, 1938) he states that "rather than the will, rather than the élan vital, Imagination is the true source of psychic production" (Bachelard, 1964, p. 110).

Sartre, in L'imaginaire (The Imaginary, 1940), found in phenomenology the method to go beyond critical metaphysics, concluding that "[...] imagination is not an empirical power added to consciousness, but is the whole of consciousness as it realizes its freedom" (Sartre, 2004b, p. 186). The metaphor of theatre is once more brought in to recognize the power of dramatic poiesis to transform the actor into character literally rather than figuratively.

The transformation that is made here is similar to that which I have discussed in the dream: the actor is entirely gripped, inspired by the irreal. It is not that the character is realized in the actor, but that the actor is irrealized in the character (Sartre, 2004b, p. 191).

Poetic imagination does not create the image nor the representation but the power of imagenesis. Accordingly, and in concordance with Ricœur (1978a), poetic imagination concerns drama more than pathos, action more than feelings, and, as it states the possibility of the unreal, as it proclaims the utopia, it transcends the sphere of discourse to impact on ideology; it surpasses the limits of individual consciousness as it establishes a social imaginary. Merleau-Ponty, as does Sartre, also appeals to the metaphor of 
the theatre, but his appeal goes in the opposite direction, claiming that philosophical thinking depends on keeping reality and imaginary separate as different stages. In Le visible et l'invisible (The Visible and the Invisible, 1964), he insists that "with the 'real' and the 'imaginary' we are dealing with two 'orders,' two 'stages,' or two 'theatres' - that of space and that of phantasms" (Merleau-Ponty, 1968, p. 39). In spite of denying imagination of reality, among Merleau-Ponty's most interesting contributions are the folded articulation of the flesh inside / outside - the chiasm - and the recognition of a generative nothingness in between, like "the darkness needed in the theatre" (Merleau-Ponty, 2002, p. 115). The antagonism between Merleau-Ponty and Sartre personalizes the drama between reality and imagination. While the former criticizes dialectics dialectically arguing that the imaginary cannot equal reality, the later advocates the imaginary action as the active power of bringing possibility together with necessity passing over any chiasm, the praxis of unification. Fighting out of the blue corner, Sartre (2004a, p. 45) considers that " $[\mathrm{i}] \mathrm{f}$ this reality is created $[\ldots]$ it can exist only in the imaginary (l'imaginaire), that is to say, as the correlative of an act of imagination". And, fighting out of the red corner, Merleau-Ponty stands to reason that " $[\mathrm{w}]$ hen [imagination] tries to impose itself on things, it suddenly returns to the unreal from which it was born. It becomes... theater" (Merleau-Ponty 1973, p. 118). Being the intention to criticize dialectical method by the way of action, theatre and imagination, it does not seem strange to me finding Sartre falling back on the sweetest of the sciences, boxing.

\section{Imagination in Drama}

As epistemology and ontology draw on theatrical terms to deal with imagination, likewise dramatic theory delves into the depths of knowledge and being. To master the creative interconnection between imagination and performance is one of the principles of every modern acting methodology. Acting permits an empirical approach to imagination while philosophy never totally escapes theoretical considerations; performance naturally turns symbols into action and vice versa. If characters appear on stage physically, it is because acting methodologies are based on the necessity of inner existence being performed out for recognition. In consequence, theory based on practice can be as much revealing as practice based on theory. 
During the first quarter of the 20th century, the spirit that sparked the pursuit of systematizing acting techniques should be considered amongst the modernization processes that pushed traditional sciences to re-structure their methodologies, and moderns - psychology, sociology, anthropology and linguistics - to consolidate. Among the most influential of Stanislavski's first generation of pupils, Vsevolod Meyerhold, Sergei Einsestein, and Michael Chekhov gathered together theatre practices and research to consolidate scientific objectivism and the transcendental philosophy of art. Addressed to theatre practitioners, in discontinuity with the dialectical confrontation between materialism and idealism, methodologies based on the psycho-physical action claim an integrative understanding of the life of human spirit because of the way creative imagination is re-considered. With the intention of veracity, in modern dramatic theories, imagination becomes crucial to conceiving of the psychosomatic performance. For dramatic verisimilitude and sense of reality, embodied imagination implies a breakthrough but not a total novelty: the subject being tied to the faculty of abstract productive synthesizing, the predominance of rational inquiry, and dialectical method are central in modern sciences. The exceptionality of Schelling's understanding of poetic imagination to surpass the opposition between sensible and intelligible, rather than a debt, represents a notable precedent for Stanislavski's spiritual naturalism. Imagination finally escapes from the domain of Logos to unify the conscious and unconscious, the object and the subject, the visible and invisible, matter and spirit. A renowned quotation from Ideen zu einer Philosophie der Natur (Ideas for a Philosophy of Nature, 1797) by Schelling (2001, p. 42), "Nature should be Mind made visible, Mind the invisible Nature" echoes this mystical power of imagination through the ancient allegory of light and the visible. Dharmatic tradition - and its own visual metaphor - must also be considered influential in Stanislavski's ideas, given the importance of creative imagination as he situates the faculty for mental productivity in the inner eye. However, the relationship between consciousness and imagination in psycho-physical acting pedagogies may have received the most influence from the Anthroposophical foundations in which Rudolf Steiner succeed melting Bruno, Schelling, Buddhism and Hinduism into Goethe, Nietzsche and Schopenhauer's philosophy of art. For his part, Michael Chekhov, one 
among the most renowned of Stanislavski's disciples, developed his methodologies directly under the influence of Anthroposophy, finding different approaches to applying his principles in practice. If imagination for Stanislavski is the inner stimulus from which external action should stream, and therefore a key dimension for an actor's consciousness to master, in addition, for Chekhov, imagination gains transcendence as the invisible energy that is recognized not only to radiate from the actor's imaginary body throughout what he called psychological gesture, but to consolidate a communicative and collective state, the atmosphere - the soul of the performance that arises from the rapport with the audience. The importance of the communicative interchange with the spectator was also especially valued by Meyerhold, who differed from Stanislavski in which the direction the actor's work should take; while Stanislavski emphasised the way that goes from the inside outwards, Meyerhold did the opposite. It is true that Stanislavski was in search of a sense of veracity dismissed in the bourgeoisie melodrama, thus he was against acting techniques based on the actor's personal clichés. He considered that only actions emerging from real inner emotion could bear the pathetic simulacrum of life (Stanislavski; Benedetti 2008).

Contrarily, Meyerhold, influenced by Pavlov's Reflexology and Taylorism, stated in his essay The Actor of the Future and Biomechanichs (1922) that inspirational methods can only bring the actor to collapse under one's own emotionality, and he chooses the way that goes from the outside inwards, prioritizing the physiological rather than the psychological (Meyerhold, 1988). If Stanislavski gives importance to the creative actor's capacities, Meyerhold focuses on the audience's imagination. As he wrote in 1907, dwelling on reception, as opposed to the limitation of naturalistic theatre and released from mimicry (Meyerhold, 1988).

Beyond the dialectics of inwards / outwards, assuming that imagination is crucial in fulfilling the communicative process both in poetics as in aesthetics, notwithstanding the categories of productive / reproductive, the most revealing understanding of imagination as an autonomous creative power sources neither from the actor nor from the spectator, but from the space in between, from the atmosphere, as Chekhov named it: a collective energetic state. Acting pedagogies are focused on developing individual skills, but those skills must consist of perceiving and 
managing a collective dynamism. Lee Strasberg, second-generation Stanislavski's continuator in the USA, also developed his acting methodology upon the actor's imagination, which is systematically trained to re-create and re-live the performance on stage (Strasberg; Cohen, 2010).

To break away from the sense-memory imaginative activation, Adler (2000) and Meisner, who participated in Strasberg's co-founded Group Theatre (1934-41), also built their methods upon dramatic imagination. Adler advocates for emotions to stream from actions in imaginative circumstances instead of actions streaming from emotions. With him, Meisner (1987, p. 128) points out: "Don't be an actor. [...] Be a human being who works off what exists under imaginary circumstances. Don't give a performance. Let the performance give you". Subtle nuances about the status of reality given to dramatic acting can finally be categorized in one of either the first or the second positions that were discussed memorably by Diderot in his posthumously published Paradoxe sur le comédien (The Paradox of Acting, 1830) - for a dramatic sense of reality, is it necessary for the actor to feel for real or, to the contrary, can dramatic imagination convert acting into reality?

Dialectical positions in classic dramatic acting theories - Stanislavski / Meyerhold, Strasberg / Adler - resonate with the argument between Sartre and Merleau-Ponty - Is the imaginary action a fallacy? I would re-consider delving any deeper into this question in order not to get caught in the recursive loop of the actor's identification / differentiation with its own phantom. Any pragmatic approach to dramatic imagination would regard acting not in terms of mimesis but in terms of transformation, of movement, of the dynamism that both the actors and spectators can run into - in terms of performance. Nikolai Evreinov, a contemporary of Stanislavski theatre practitioner, alludes to theatricality not as a metaphor but as an actual instinct of all forms of life; he insists that "[...] fancy is the basis of all arts and that the power of imagination would not be power at all if it could not transform non-existing things into existing ones" (Evreinov, 2013, p. 190). The radical claim of performance during the second half of the 20th century has led some critics to dialectically confront performativity and theatricality, overshadowing the performative core of theatre, the theatrical dimension of performance, and the common role of imagination 
to connect the physical with the symbolic, the visible with the invisible, both in arts as in ordinary life.

\section{Conclusion: the virtual drama of identity}

While critical imagination has been widely discussed, careful imaginative criticism is still pending. I agree with Zarrilli (2009, p. 39) on "[...] how unimaginatively we have conceived of the imagination" and the excessive importance given to the forms probably has much to do with it. Heir of Russian symbolism which celebrates the creative power of language, Evreinov (2013, p. 63) synthesizes in one sentence the dependence between imagination, theatricality and identity: "[to] imagine oneself different from that which one really is, is the very essence of theatricality". Nevertheless, the evidence of a ready-made self is equivocal to the assumption of the identification between the actor and the character, of the existence of a non-imaginative consciousness that could stay away from drama, of the possibility of an identity theatrically be sourced from anything other than from the repetitive differentiation with a constitutive opposite. Dramatization is dynamism, a repetitive series of spatio-temporal determinations, and the dramatic procedure by which the subject presents itself in existence can be considered a ritualized virtuality because of its theatrical repetitive condition. Therefore, and through repetition, the subject cannot be identified but differentiated - that is the Deleuzean understanding of individuation as a dramatic incarnation (1993 [1968]). Repetition relates to actualization and is contrary to representation. The here and now claimed by every acting system refers to this need of presence, of differential presence (Cull, 2009): that which cannot be portrayed but enacted, not represented but presented over and over. As life is theatrical per $s e$, representative theatre becomes reiterative and exhausts any possibility of dynamism in the same way that identity does: it has the ability to construct a stable existence which is equal to itself and able to show up in multiple iterations without transforming its own essence. In consequence, the role of imagination is "to draw something new from repetition, to draw difference from it", and so, concerning spatio-temporal embodiment, "it is imagination which must grasp the process of actualisation" (Deleuze, 1994, p. 76; 220). Imagination is action in essence, and, as every action, it acquires its capacity of transformation from the power of imagination - a virtual 
power that becomes actual within the rapport between actors and spectators. The understanding of imagination to mean action disentangles the literal ties with visible forms - it is neither iconicity nor resemblance which describes imagination, but motion, the capacity to transform. What I call dramatic imagination summarizes the transpersonal generative activity from that which derivates free consciousness. More than to state an evasive mimicry that resembles reality, imagination - considered as performance is able to defy reality through a virtual state which ratifies the invisible dimension of a permanent mutable nature. As it connects dynamically to thinking, feeling, and acting, dramatic imagination concerns identity, the theatre of the self. Any psychological consideration of the individual must be subordinated to the intersubjective bare stage that imagination establishes in zero degree - that empty but active space-time - which preexists and enables the drama of existence. The consideration of that virtual scene as an imaginative vacuum transcends the apparently unavoidable dichotomy between ontology and epistemology, between the transcendental Sein and the situated Dasein, according to which Heidegger seized existential phenomenology. If the dialectic method searches for identities diacritically splitting otherness, it seems reasonable to raise this question: "Would not imagination have something to do with the conflict between identity and difference?" (Ricour, 2006, p. 235). As an alternative to the schematizing Einbildungskraft, dramatic imagination recognizes constitutive difference not as the result of the process of differentiation, but as a creative power sustained by the temporary cancellation of the ego and its alter. In other words, the dialectics of identity can never resolve the ethical dilemma between the self and the other - as they establish their existence reciprocally. In contrast, dramatic imagination infers the existent from existence, the actor from the theatre, the self from its absolute absence. It is important to notice that not all dualisms are dialectical: if Fichte's Ich (ego) and Nicht-Ich (non-ego) constitute a typical thesis-antithesis dialectical scheme (Science of Knowledge, 1982 [1794]), contrarily, Levinas' (1987, p. 46) discussion of existence and nothingness is sustained on an imaginary state of reasoning, on a suspension of dialectics close to the Buddhist concept of Anatta: "The absence of everything returns as a presence".

In addition to that conception of nothingness which does not deny the possibility of existence - contrary to that nothingness that led 
Heidegger to anguish - but instead makes the there is possible, it is important to emphasize imagination as a method of inquiry, a method to which Levinas also resorted in De l'existence à l'existant (Existence and Existents, 2004 [1947]). The Spanish philosopher María Zambrano (2011) named it razón poética (poetic reason), a method that builds on itself, a method through which the truth gets revealed imaginatively (Zambrano, 1996), a method that concerns empathy, feelings and love, and, the same as Levinas' imaginary vacuum, that makes it possible for ethics to hold otherness beyond the antagonistic differentiation inherent in dialogical reason.

Naturally, every attempt of overcoming the metaphysical limitations of the dialectical method - whether that would be through the path of the phenomenology, deconstruction or absurdity - has ended in reconsidering individual imagination and, in consequence, the autonomous subject -that pre-existent entity inside whom and by the use of whose imaginative powers reality becomes meaningful subjectively. In concert with Hüppauf and Wulf (2009, p. 4), I agree that "[...] imagination needs to be lifted from its flawed history and reconsidered as an indispensable faculty for an understanding of modernity and its images at the time of its reconstitution". Imagination in terms of performance - dramaginaction defies the limits of subjectivity in relation both to the autonomy of the subject (the micro-internal) and the existence of reality (the macroexternal). Dramatic imagination is a dynamic-transformative energy that streams from an unformed transpersonal source, that which Castoriadis denominated magma (1975; 1997b), to be pre-existent for any temporary consideration of the subject and the object - the actor and the character.

[I]t is because radical imagination exists that 'reality' exists for us - exists tout court - and exists as it exists (Cornelius Castoriadis, 1997a, p. 321).

This radical understanding of imagination becomes relevant to the institution of society and of political relevance in consequence. The revolutionary slogan raised in the streets during May 1968 L'imagination au pouvoir (Power to the Imagination) gathered together Marxism with surrealism. The former inherited the Frankfurt School's recognition of social unconsciousness and critical thinking to subvert establishment empowered imagination splits between aesthetics and poiesis, between subject and object, and can be considered in continuity with the Hegelian 
dialects of history. Let's say that the fruits of that subversive imagination that Marcuse (2007 [1964]) recognizes as a "space within", a space of resistance opposed to the materialism of a society devoid of any transcendence, can pull away significative transformations when dumped into social reality. Facts make us reconsider for how long imaginative transcendent utopias can maintain their subversive capacities once engulfed in society by institutional bureaucracy. In contrast, the clarifying of metaphysical determination by radical surrealism considered reality as an imaginary series of temporary and random determinations; instead of advocating for another logic to be possible, it abrogates the possibility of logic itself. As an alternative to the hierarchy of logical reason, dramatic imagination permanently criticizes dialectical history, a criticism that together with drama (action) makes pathos (feelings) and ethos (morals) of primary importance. That which pre-exists is nothing but the imaginative capacity of transformation.

Opposing religious dogmatism, dialectic methodology is recognized to push criticism forward in spite of its limitations in dealing with constitutive difference. Between ideas and representative images there exists a dissimilitude of just a degree: imitating forms or images do not reach the truth nor deny it. Simulacra, fake copies, those are what voids ideas. Now, in contemporary times, given the superabundance of visual stimuli, when phantoms are neither recognizable nor even matter, veracity loses its value under the rise of post-truth politics. Deleuze (1969) discussed simulacrum to conclude that an inversion of Platonism is already fulfilled. In our specular societies, images are just images of images, and forms, even keeping appearance, lose dramatism, that is to say, capacity for transformation. Since the profusion of technical mechanism reflecting life in real time, overwhelmed by our own mimicry, the theatre of existence become stuck to the pathos: social media is the global stage for actors to reiteratively project an inorganic self and manufacture mannerisms. The lavish array of images does not necessarily imply excessive imagination, quite the opposite, in fact. To maintain the phantasy of the self, trying to attain an identity, imagination exhausts actuality to the detriment of any dynamism. Hence the importance of memory in dramatic transformation, hence the lack of temporality in virtual exhibitionism. 


\section{Revista Brasileira de Estudos da Presença Brazilitan Journal on Presence Studies}

E-ISSN 2237-2660

\section{Epilogue: the evening of the fight}

I went back to the boxing gym to take a picture of Galeano's quote on the wall for this article. It was a Friday evening in late January when I showed up by surprise in my colleague's gym with my camera. I waited for the silhouettes of the bodies, for the movements of the fighters to give veracity to my photographs but nobody was there training, just the cleaning crew. A worker told me that the main hopeful of the gym, a girl in her twenties who actually holds a regional title after having overcome a dramatic youth of abuses, was fighting that evening. I found myself alone, standing by the bare stage while the big show was happening elsewhere. Dance halls and boxing gyms always have mirrors. Under the pilot lights, my shadowed presence by the silent ring was offering me through the mirror a totally different perspective of myself. Not even the poster remained there. In its place I found a quotation by the legendary Muhammad Ali: "The man who has no imagination has no wings". I then realized that I was giving excessive credit to the visible. Imagination is never illustrative.

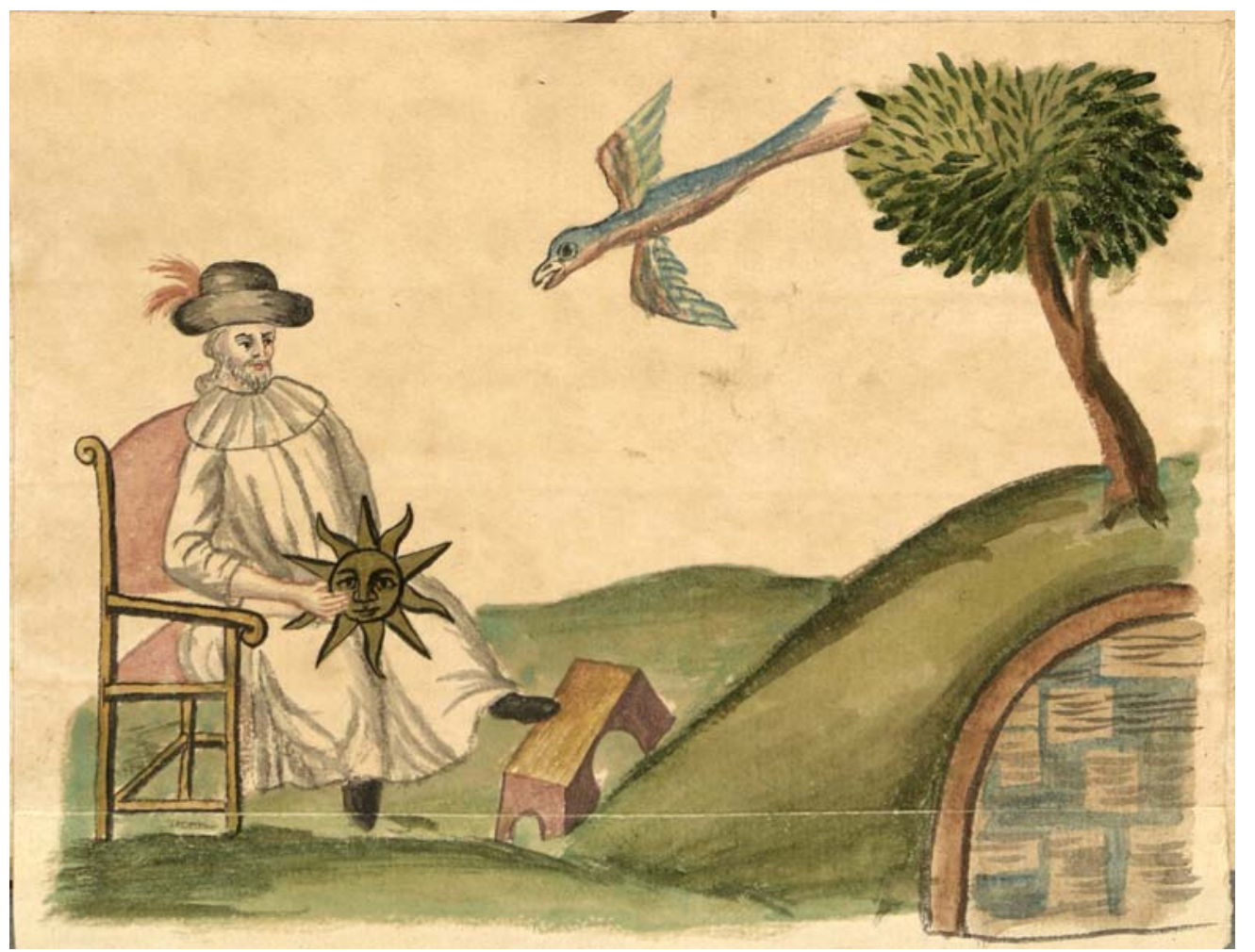

Figure 3 - Manuscript Zoroaster Clavis Artis, Ms-2-27. Source: Biblioteca Civica Hortis, Trieste, v. 2, p. 72. 


\section{Note}

1 Lou Reed. This magic moment. Pomus \& Shuman. Warner Chappell. Music, Inc., Spirit Music Group.

\section{References}

ADLER, Stella. Stella Adler: the art of acting. New York: Applause Books, 2000.

ARISTOTLE. Works. Translated into English under the editorship of W.D. Ross. Oxford: Clarendon Press, 1908. 12v.

ARISTOTLE. De anima: books II and III with passages from book 1. Transl. D. W. Hamlyn. Oxford; New York: Clarendon Press; Oxford University Press, 1993. (Clarendon Aristotle series).

BACHELARD, Gaston. La Poétique de l'Espace. 3. ed. Paris: Presses Universitaires de France, 1961.

BACHELARD, Gaston. The psychoanalysis of fire. Transl. Allan C. M. Ross. London: Routledge \& Kegan Paul, 1964.

BACHELARD, Gaston. L'eau et les rêves: essai sur l'imagination de la matière. 16 ed. Paris: Librairie José Corti, 2016.

BAUMAN, Zygmunt. From Pilgrim to Tourist or a Short History of Identity. In: HALL, Stuart; DU GAY, Paul (Org.). Questions of cultural identity. London: Sage, 1996. P. 18-37.

BRUBAKER, Rogers; COOPER, Frederick. Beyond 'Identity'. Theory and Society, Netherlands, v. 29, n. 1, p. 1-47, 2000.

BRUNO, Giordano. Jordani Bruni Nolani Opera Latine Conscripta Publicis Sumptibus Edita. III v. Neapoli: D. Morano, 1879.

CASTORIADIS, Cornélius. L'Institution Imaginaire de la Société. 1. ed. Paris: Seuil, 1975.

CASTORIADIS, Cornelius. The Logic of Magmas and the Question of Autonomy. In: CURTIS, David Ames (Ed.). The Castoriadis reader. Oxford; Cambridge, Mass: Blackwell Publishers, 1997a. P. 290-318. (Blackwell readers).

CASTORIADIS, Cornelius. Radical Imagination and the Social Instituting Imaginary. In: CURTIS, David Ames (Ed.). The Castoriadis reader. Oxford; Cambridge, Mass.: Blackwell Publishers, 1997b. P. 319-337. (Blackwell readers). 
COLERIDGE, Samuel Taylor. Biographia literaria, or, Biographical sketches of my literary life and opinions. Princeton: Princeton University Press, 1984. (Bollingen series, 75).

CORBIN, Henry. Spiritual body and celestial Earth: from Mazdean Iran to Shī‘ite Iran. Princeton, N.J: Princeton University Press, 1989.

CULL, Laura. How Do You Make Yourself a Theatre without Organs? Deleuze, Artaud and the Concept of Differential Presence. Theatre Research International, Cambridge, v. 34, n. 03, p. 243-255, 2009.

DELEUZE, Gilles. Platon et le simulacre. In: DELEUZE, Gilles. Logique du Sens. Paris: Editions de Minuit, 1969. P. 292-306. (Collection 'Critique').

DELEUZE, Gilles. Fourth lesson on Kant, 4 April 1978. Transl. Melissa McMahon. Available on: <https://www.webdeleuze.com/textes/65>. Accessed: 18 November 2019.

DELEUZE, Gilles. Différence et Répétition. 7. ed. Paris: PUF, 1993.

DELEUZE, Gilles. Difference and Repetition. New York: Columbia University Press, 1994.

DELEUZE, Gilles. La méthode de dramatisation. In: DELEUZE, Gilles. L'île Déserte et Autres Textes: textes et entretiens, 1953-1974. Paris: Editions de Minuit, 2002. P. 131-162. (Paradoxe).

DIMSDALE STOCKER, Richard. The God Which Is Man. The Message of Human Idealism. Whitefish, MT: Literary Licensing LLC, 2014.

DONNELlAN, Declan. The Actor and the Target. St. Paul, Min.: Theatre Communications Group, 2008.

DURAND, Gilbert. Les Structures Anthropologiques de l'Imaginaire. Introduction à l'archétypologie générale. 1. ed. Paris: Bordas, 1960.

DURAND, Gilbert. L'Imagination Symbolique. 1. ed. Paris: PUF, 1964.

EVREINOV, Nicolas N. Theatre in Life. Transl. Alexander I Nazaroll, Oliver M Sayler; Boris Aronson. Mansfield Centre, CT: Martino Publishing, 2013.

FAIVRE, Antoine. Theosophy, imagination, tradition: studies in Western esotericism. Albany. New York: State University of New York Press, 2000.

FICHTE, Johann Gottlieb. Science of Knowledge with the First and Second introductions. Cambridge [Cambridgeshire]; New York: Cambridge University Press, 1982. (Texts in German philosophy). 
FLUDD, Robert. Utriusque cosmi maioris scilicet et minoris metaphysica, physica atque technica historia in duo volumina secundum cosmi differentiam diuisa authore Roberto Flud aliàs de Fluctibus. Tomi secundi tractatus primi, sectio secunda, de technica microcosmi historia, in portiones VII divisa. [s.l.: s.n.], 1619. Available at: <https://archive.org/details/ bub_gb_54F9a5YOVCsC>. Accessed on: 23 April 2019.

GALEANO, Eduardo. El libro de los abrazos. 13. ed. Buenos Aires: Siglo Veintiuno, 2016.

HÜPPAUF, Bernd-Rüdiger; WULF, Christoph (Org.). Dynamics and performativity of imagination: the image between the visible and the invisible. New York: Routledge, 2009. (Routledge research in cultural and media studies, 21).

KANT, Immanuel. Lectures on metaphysics. Cambridge, UK; New York: Cambridge University Press, 1997.

LÉVINAS, Emmanuel. Time and the Other and Additional Essays. Pittsburgh: Duquesne University Press, 1987.

LÉVINAS, Emmanuel. De l'Existence à l'Existant. 2. ed. augm. 8. tirage. Paris: Vrin, 2004. (Bibliothèque des textes philosophiques).

LÉVI-STRAUSS, Claude. L'Identité Séminaire Interdisciplinaire, 1974-1975. Paris: Presses Universitaires de France, 1983. (Quadrige).

MARCUSE, Herbert. One-dimensional man: studies in the ideology of advanced industrial society. Transl. Douglas Kellner. Repr. London: Routledge, 2007. (Routledge classics Philosophy).

MEISNER, Sanford; LONGWELL, Dennis. Sanford Meisner on acting. 1. ed. New York: Vintage Books, 1987.

MERLEAU-PONTY, Maurice. The visible and the invisible: followed by working notes. Transl. Claude Lefort. Evanston: Northwestern University Press, 1968. (Northwestern University studies in phenomenology \& existential philosophy).

MERLEAU-PONTY, Maurice. Adventures of the Dialectic. Transl. Joseph Bien. Evanston: Northwestern University Press, 1973. (Northwestern University studies in phenomenology \& existential philosophy).

MERLEAU-PONTY, Maurice. Phenomenology of Perception. London; New York: Routledge, 2002. 
MEYERHOLD, Vsevolod Emilievich. Meyerhold on Theatre. Transl. Edward Braun. London: Methuen, 1988.

PICO DELLA MIRANDOLA, Giovanni et al. Oration on the dignity of man: a new translation and commentary. New York: Cambridge University Press, 2012.

PLATNER, Ernst. Ernst Platners Neue Anthropologie für Aerzte und Weltweise: Mit besonderer Rücksicht auf Physiologie, Pathologie, Moralphilosophie und Aesthetik Bd. 1 Bd. 1. Leipzig: Dyck, 1791.

PLATO et al. Plato in twelve volumes: with an English translation. London; Cambridge: W. Heinemann; Harvard University Press, 1914.

PLOTINUS. Plotinos: complete works, in chronological order, grouped in four periods: with biography by Porphyry, Eunapius, \& Suidas, commentary by Porphyry, illustrations by Jamblichus \& Ammonius, studies in sources, development, influence; index of subjects, thoughts and words. Trad. Kenneth Sylvan Guthrie. Alpine, N. J.: Plotonist Press, 1918.

PROCLUS. Commentary on Plato's Timaeus. Volume III, book 3, part I, Volume III, book 3, part I, Cambridge; New York: Cambridge University Press, 2007.

PULTAR, Gönül (Org.). Imagined Identities: identity formation in the age of globalization. First Edition. Syracuse: Syracuse University Press, 2014.

RICCEUR, Paul. Imagination in Discourse and in Action. In: TYMIENIECKA, Anna-Teresa (Org.). The Human Being in Action. Dordrecht: Springer Netherlands, 1978a. P. 3-22.

RICEEUR, Paul. The Metaphorical Process as Cognition, Imagination, and Feeling. Critical Inquiry, Chicago, v. 5, n. 1, p. 143-159, 1978 b.

RICEER, Paul. The Rule of Metaphor: the creation of meaning in language. London: Routledge, 2006. (Routledge classics).

SARTRE, Jean-Paul. Critique of Dialectical Reason. Edited by Arlette ElkaïmSartre and Quintin Hoare. London; New York: Verso, $2004 \mathrm{a}$.

SARTRE, Jean-Paul. The imaginary. A phenomenological psychology of the imagination. Transl. Jonathan Webber. London; New York: Routledge, $2004 \mathrm{~b}$.

SCHOTT, Gaspar. Mechanica hydraulico-pneumatica. Frankfurt: J. G. Schönwetteri, 1657. 
SHULMAN, David Dean. More than Real: A History of the Imagination in South India. Cambridge, Mass.: Harvard University Press, 2012.

SCHELLING, Friedrich Wilhelm Joseph von. Ideas for a philosophy of nature as introduction to the study of this science. Transl. Errol E. Harris; Peter Heath. Cambridge [Cambridgeshire]; New York: Cambridge University Press, 2001.

STANISLAVSKI, Konstantin; BENEDETTI, Jean. An Actor's Work: a student's diary. London; New York: Routledge, 2008.

STRASBERG, Lee; COHEN, Lola. The Lee Strasberg Notes. London; New York: Routledge, 2010.

ZAMBRANO, María. Filosofía y poesía. 4. ed. México: Fondo de Cultura Económica, 1996.

ZAMBRANO, María. Notas de un método. Madrid: Tecnos, 2011.

ZARRILLI, Phillip B. Psychophysical Acting: an intercultural approach after Stanislavski. London; New York: Routledge, 2009.

Rubén Vega Balbás. aka Rubén Vejabalbán, is an artist, scholar, and polymath in imagination and research in artistic creativity. Works on performance and philosophy, dramatic theory, cybernetic art, communicative devices, and pedagogy of the arts. Holds a $\mathrm{PhD}$ in Applied Creativity (Universidad Complutense de Madrid). Founder of the Centro Imaginario de Estudios Artísticos (Madrid, Spain). Member of the Nebrija ComAcAr Research Group.

ORCID: http://orcid.org/0000-0001-6862-9081

E-mail: ruvebal@crea-comm.net

This original text is also published in Portuguese in this issue of the journal.

Received on April 25, 2019 Accepted on October 22, 2019

Editor-in-charge: Ana Paula Hofling Editor-in-charge: Laura Cull Ó Maoilearca Editor-in-charge: Luciana da Costa Dias

This is an open-access article distributed under the terms of the Creative Commons Attribution License 4.0 International. Available at: <http://creative commons.org/licenses/by/4.0>. 